\title{
Distribution of Vitamin $\mathbf{B}_{12}$, Thiamine and Biotin in Marine Sediments*
}

\author{
Kouichi OHWADA** and Nobuo TAGA**
}

\begin{abstract}
Vitamin $\mathrm{B}_{12}$, thiamine and biotin in the sediments collected from different 41 stations at the Eastern China Sea, the Pacific Ocean and the bays and inlet along the Pacific coast of Japan have been determined by microbiological assay methods using Lactobacillus leichmannii, Lactobacillus fermenti and Sacharomyces cerevisiae respectively. Vitamin $\mathrm{B}_{12}$ contents in the surface sediments were rather higher at such a shallow area as the Aburatsubo Inlet (1.14$7.14 \mathrm{~m} \mu \mathrm{g} / \mathrm{g}$ ) than those at other areas, the Japan Trench, the Mid-Pacific Ocean, the Eastern China Sea, the Suruga Bay and the Sagami Bay $(0-2.10 \mathrm{~m} \mu \mathrm{g} / \mathrm{g})$. Thiamine contents were similar levels in the sediments at all areas investigated (average of $0.31 \mu \mathrm{g} / \mathrm{g}$ ), whereas, biotin was more abundant in the sediments at the Mid-Pacific Ocean (average of $5.0 \mathrm{~m} \mu \mathrm{g} / \mathrm{g}$ ) than the other areas (average of $2.0 \mathrm{~m} \mu \mathrm{g} / \mathrm{g}$ ). Vertical distribution of vitamin concentrations in the cores revealed, in general, the gentle decreasing trends with depth, except for a few irregular fluctuations. In comparing the relationship between vitamin contents and some of the environmental factors in the sediments, significant correlations were observed between vitamin $B_{12}$ or thiamine contents and values of loss on ignition. On the other hand, there seemed to be no clear relation between biotin contents and values of loss on ignition.
\end{abstract}

\section{Introdnction}

Vitamin $\mathrm{B}_{12}$, thiamine and biotin have been shown to be required indispensably by certain marine unicellular algae, which play the important role as primary producers in marine ecosystem. After their reviewing the accumulated informations, Droop (1962) and Provasoli (1963) reported that some $60 \%$ of strains of algae so far studied proved to be auxotrophs, $80 \%$ of them required vitamin $\mathrm{B}_{12}, 53 \%$ thiamine, and $10 \%$ biotin. In recent years, considerable interest has centered also around the possible role of these vitamins in the outbreak of algal bloom and in the succession of algal population, because available concentration of vitamins in the aquatic environment might often regulate the algal production. Subsequently to the aforementioned scope, the vitamin cycles in the sea should be comprehended extensively for the evaluation of the importance of these vitamins in marine ecology.

Informations on the distribution of vitamin $B_{12}$, thiamine and biotin in sea water have been accumulated, and were reviewed by PROVASOLI (1963).

* Received January 29, 1969

** Ocean Research Institute, University of Tokyo
As for the distributions of vitamins in marine sediments, although BURKHOLDER and BURKHOLDER (1956) and STARR (1956) measured very high concentrations of vitamin $B_{12}$ in the marsh muds compared with others found in sea water, the extensive data are so scarce up to now.

This paper describes the results of assays for vitamin $\mathrm{B}_{12}$, thiamine and biotin in the sediments collected from different 41 stations at the Eastern China Sea, the Pacific Ocean and its adjacent bays around Japan. Environmental factors in relation to the vitamin contents are also discussed.

\section{Materials and Methods}

\section{Collection of sediment samples}

The locations of sampling stations where the samples were collected, dates of sampling, depths of water and types of sediments are shown in Table 1. The charts of the sampling stations at the Aburatsubo Inlet, the Japan Trench and the Eastern China Sea, the Mid-Pacific Ocean, the Suruga Bay and the Sagami Bay are shown in Fig. 1, Fig. 2, Fig. 3 and Fig. 4 respectively. The sediment samples from the Japan Trench (St. 1, St. 2, St. 3 and St. 4) were collected during the cruise of the Leg IV of Zetes (Depac 
Table 1. Locations and types of sediments used in the present study.

\begin{tabular}{|c|c|c|c|c|c|}
\hline \multirow{2}{*}{$\begin{array}{l}\text { Station } \\
\text { number }\end{array}$} & \multicolumn{2}{|c|}{ Location } & \multirow{2}{*}{ Date } & \multirow{2}{*}{$\begin{array}{c}\text { Depth of } \\
\text { water }(\mathrm{m})\end{array}$} & \multirow{2}{*}{$\begin{array}{c}\text { Type of } \\
\text { sediment }\end{array}$} \\
\hline & Latitude & Longitude & & & \\
\hline 1 & $33^{\circ} 37^{\prime} \mathrm{N}$ & $141^{\circ} 58^{\prime} \mathrm{E}$ & May 31,1966 & 9,247 & clay \\
\hline 2 & $30^{\circ} 42^{\prime} \mathrm{N}$ & $142^{\circ} 25^{\prime} \mathrm{E}$ & June 3,1966 & 9,628 & clay \\
\hline 3 & $32^{\circ} 05^{\prime} \mathrm{N}$ & $142^{\circ} 06^{\prime} \mathrm{E}$ & June 3,1966 & 9,489 & clay \\
\hline 4 & $33^{\circ} 59^{\prime} \mathrm{N}$ & $140^{\circ} 26^{\prime} \mathrm{E}$ & June $\quad 4,1966$ & 1,660 & silt \\
\hline 5 & $39^{\circ} 49^{\prime} \mathrm{N}$ & $145^{\circ} 44^{\prime} \mathrm{E}$ & Aug. 10, 1967 & 5,205 & clay \\
\hline 6 & $38^{\circ} 28^{\prime} \mathrm{N}$ & $145^{\circ} 49^{\prime} \mathrm{E}$ & Aug. 11, 1967 & 5,250 & clay \\
\hline 7 & $38^{\circ} 49^{\prime} \mathrm{N}$ & $143^{\circ} 00^{\prime} \mathrm{E}$ & Aug. 13, 1967 & 1,600 & silt \\
\hline 8 & $38^{\circ} 39^{\prime} \mathrm{N}$ & $144^{\circ} 08^{\prime} \mathrm{E}$ & Aug. 14, 1967 & 7,370 & clay \\
\hline 9 & $00^{\circ} 00^{\prime} \mathrm{N}$ & $150^{\circ} 05^{\prime} \mathrm{E}$ & Dec. 27,1967 & 5,235 & clay \\
\hline 10 & $00^{\circ} 40^{\prime} \mathrm{S}$ & $160^{\circ} 37^{\prime} \mathrm{E}$ & Jan. $\quad 5,1968$ & 2,940 & foram. ooze \\
\hline 11 & $00^{\circ} 49^{\prime} \mathrm{N}$ & $164^{\circ} 00^{\prime} \mathrm{E}$ & 6,1968 & 4,330 & foram. ooze \\
\hline 12 & $02^{\circ} 18^{\prime} \mathrm{N}$ & $167^{\circ} 00^{\prime} \mathrm{E}$ & 7,1968 & 4,260 & foram. ooze \\
\hline 13 & $03^{\circ} 28^{\prime} \mathrm{N}$ & $170^{\circ} 09^{\prime} \mathrm{E}$ & 8,1968 & 4,450 & clay \\
\hline 14 & $05^{\circ} 10^{\prime} \mathrm{N}$ & $173^{\circ} 08^{\prime} \mathrm{E}$ & 9,1968 & 4,850 & clay \\
\hline 15 & $07^{\circ} 42^{\prime} \mathrm{N}$ & $177^{\circ} 54^{\prime} \mathrm{E}$ & Jan. 11,1968 & 5,400 & clay \\
\hline 16 & $18^{\circ} 04^{\prime} \mathrm{N}$ & $175^{\circ} 13^{\prime} \mathrm{W}$ & Jan. 17,1968 & 1,450 & foram. ooze \\
\hline 17 & $12^{\circ} 17^{\prime} \mathrm{N}$ & $174^{\circ} 16^{\prime} \mathrm{W}$ & Jan. 19,1968 & 5,000 & clay \\
\hline 18 & $31^{\circ} 23^{\prime} \mathrm{N}$ & $128^{\circ} 10^{\prime} \mathrm{E}$ & May 19,1968 & 150 & coarse sand \\
\hline 19 & $31^{\circ} 36^{\prime} \mathrm{N}$ & $128^{\circ} 10^{\prime} \mathrm{E}$ & May 19,1968 & 141 & coarse sand \\
\hline 20 & $31^{\circ} 42^{\prime} \mathrm{N}$ & $127^{\circ} 19^{\prime} \mathrm{E}$ & May 20,1968 & 123 & fine sand \\
\hline 21 & $31^{\circ} 43^{\prime} \mathrm{N}$ & $126^{\circ} 48^{\prime} \mathrm{E}$ & May 20,1968 & 103 & fine sand \\
\hline 22 & $31^{\circ} 47^{\prime} \mathrm{N}$ & $125^{\circ} 52^{\prime} \mathrm{E}$ & May 20,1968 & 70 & silt \\
\hline 23 & $31^{\circ} 47^{\prime} \mathrm{N}$ & $125^{\circ} 09^{\prime} \mathrm{E}$ & May 20,1968 & 45 & silt \\
\hline 24 & $31^{\circ} 50^{\prime} \mathrm{N}$ & $124^{\circ} 32^{\prime} \mathrm{E}$ & May 20,1968 & 40 & fine sand \\
\hline 25 & $31^{\circ} 51^{\prime} \mathrm{N}$ & $124^{\circ} 01^{\prime} \mathrm{E}$ & May 20,1968 & 42 & coarse sand \\
\hline 26 & $30^{\circ} 56^{\prime} \mathrm{N}$ & $124^{\circ} 58^{\prime} \mathrm{E}$ & May 21,1968 & 58 & fine sand \\
\hline 27 & $30^{\circ} 33^{\prime} \mathrm{N}$ & $125^{\circ} 18^{\prime} \mathrm{E}$ & May 21,1968 & 62 & fine sand \\
\hline 28 & $30^{\circ} 08^{\prime} \mathrm{N}$ & $125^{\circ} 43^{\prime} \mathrm{E}$ & May 21,1968 & 76 & fine sand \\
\hline 29 & $29^{\circ} 52^{\prime} \mathrm{N}$ & $126^{\circ} 01^{\prime} \mathrm{E}$ & May 21,1968 & 88 & fine sand \\
\hline 30 & $29^{\circ} 25^{\prime} \mathrm{N}$ & $126^{\circ} 28^{\prime} \mathrm{E}$ & May 22,1968 & 97 & fine sand \\
\hline 31 & $28^{\circ} 40^{\prime} \mathrm{N}$ & $126^{\circ} 49^{\prime} \mathrm{E}$ & May 22, 1968 & 192 & fine sand \\
\hline 32 & $30^{\circ} 26^{\prime} \mathrm{N}$ & $124^{\circ} 31^{\prime} \mathrm{E}$ & May 23, 1968 & 64 & fine sand \\
\hline 33 & $29^{\circ} 52^{\prime} \mathrm{N}$ & $124^{\circ} 29^{\prime} \mathrm{E}$ & May 23,1968 & 66 & fine sand \\
\hline 34 & $29^{\circ} 10^{\prime} \mathrm{N}$ & $124^{\circ} 32^{\prime} \mathrm{E}$ & May 23,1968 & 80 & fine sand \\
\hline 35 & $28^{\circ} 28^{\prime} \mathrm{N}$ & $124^{\circ} 51^{\prime} \mathrm{E}$ & May 23,1968 & 105 & fine sand \\
\hline 36 & $28^{\circ} 00^{\prime} \mathrm{N}$ & $125^{\circ} 00^{\prime} \mathrm{E}$ & May 24,1968 & 103 & coarse sand \\
\hline 37 & $27^{\circ} 24^{\prime} \mathrm{N}$ & $125^{\circ} 00^{\prime} \mathrm{E}$ & May 24,1968 & 103 & coarse sand \\
\hline 38 & $26^{\circ} 54^{\prime} \mathrm{N}$ & $125^{\circ} 00^{\prime} \mathrm{E}$ & May 24, 1968 & 121 & coarse sand \\
\hline 39 & $34^{\circ} 56^{\prime} \mathrm{N}$ & $138^{\circ} 36^{\prime} \mathrm{E}$ & Oct. 10,1968 & 835 & fine sand \\
\hline 40 & $35^{\circ} 00^{\prime} \mathrm{N}$ & $138^{\circ} 59^{\prime} \mathrm{E}$ & Oct. 11,1968 & 1,425 & fine sand \\
\hline 41 & $35^{\circ} 07^{\prime} \mathrm{N}$ & $139^{\circ} 25^{\prime} \mathrm{E}$ & Oct. 13,1968 & 1,120 & fine sand \\
\hline
\end{tabular}

X) Expedition of the Scripps Institution of Oceanography, University of California, by $\mathrm{R} / \mathrm{V}$ Argo (REID, 1966; SEKI and ZOBELL, 1967). The other samples at the Japan Trench, the sediments at the Mid-Pacific Ocean area and at the Eastern China Sea area were taken during the cruise of KH-67-2, KH-68-2 respectively by
R/V Hakuho-maru of the Ocean Research Institute, University of Tokyo. The samples at the Suruga Bay and the Sagami Bay were collected during the cruise of KT-68-20 by R/V Tanseimaru of the same Institute. The other samples at the Aburatsubo Inlet were taken by the boat of the Misaki Marine Biological Station, Univer. 


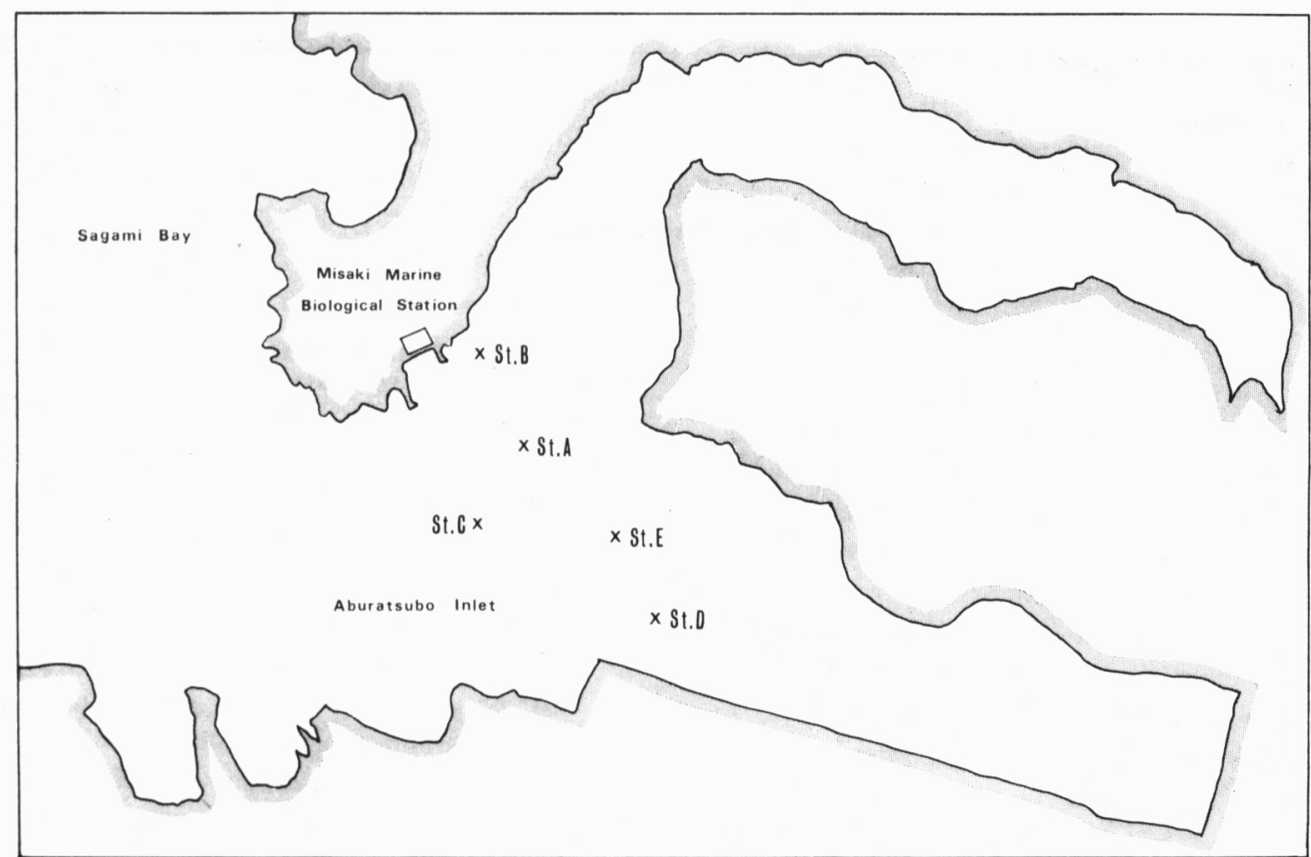

Fig. 1. Sampling stations in the Aburatsubo Inlet.

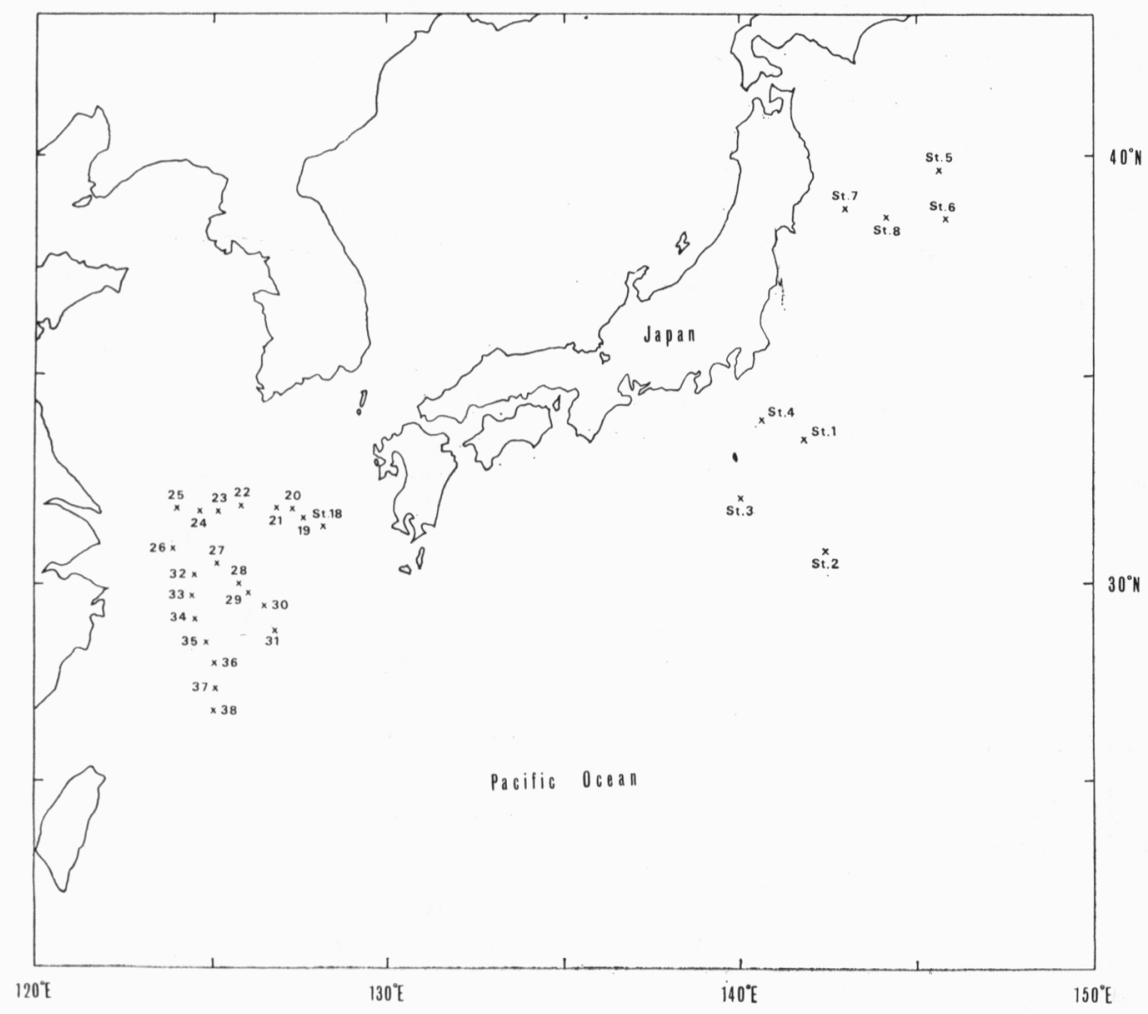

Fig. 2. Map of sampling stations at the Japan Trench and the East China Sea. 


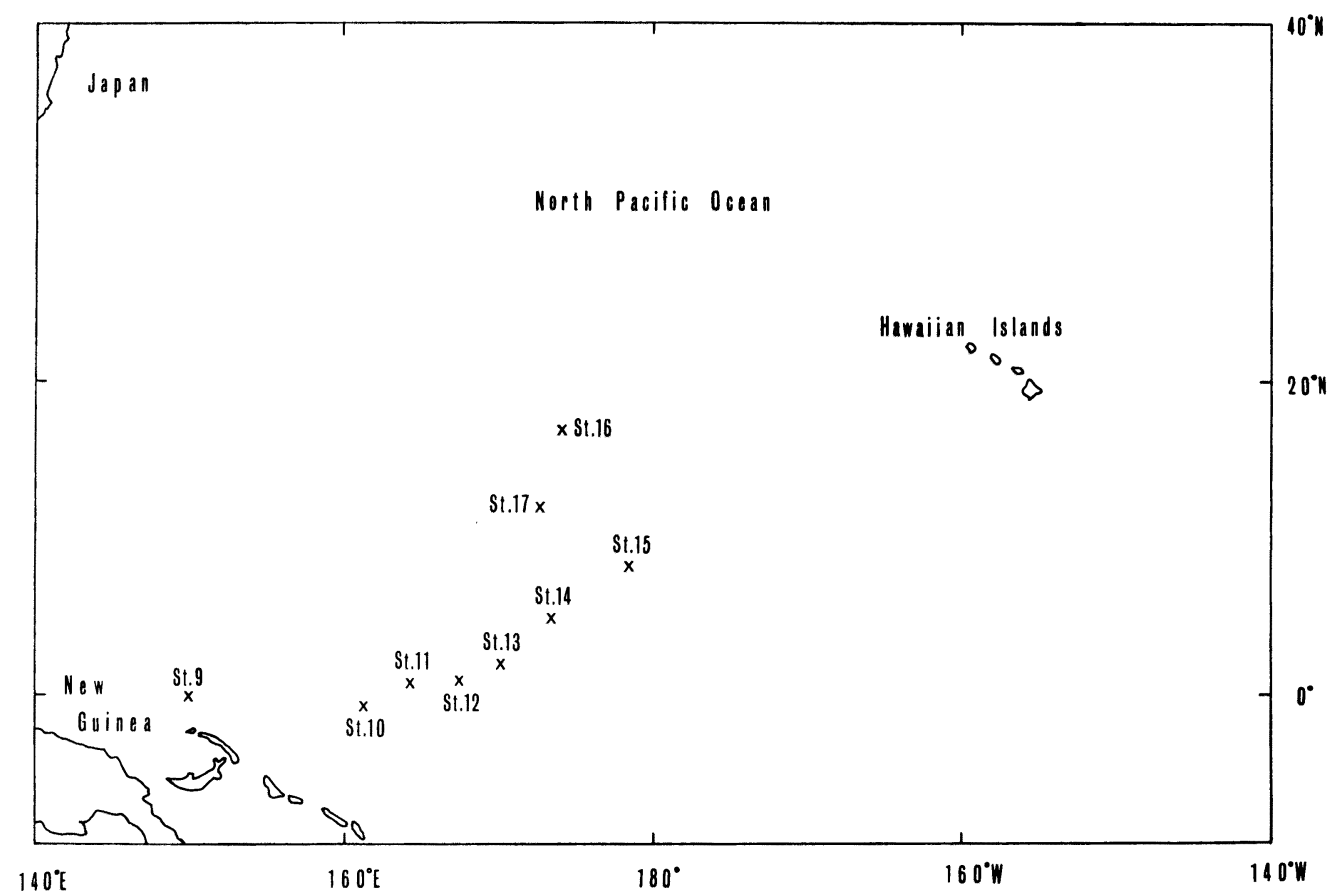

Fig. 3. Map of sampling stations at the Mid-Pacific Ocean.

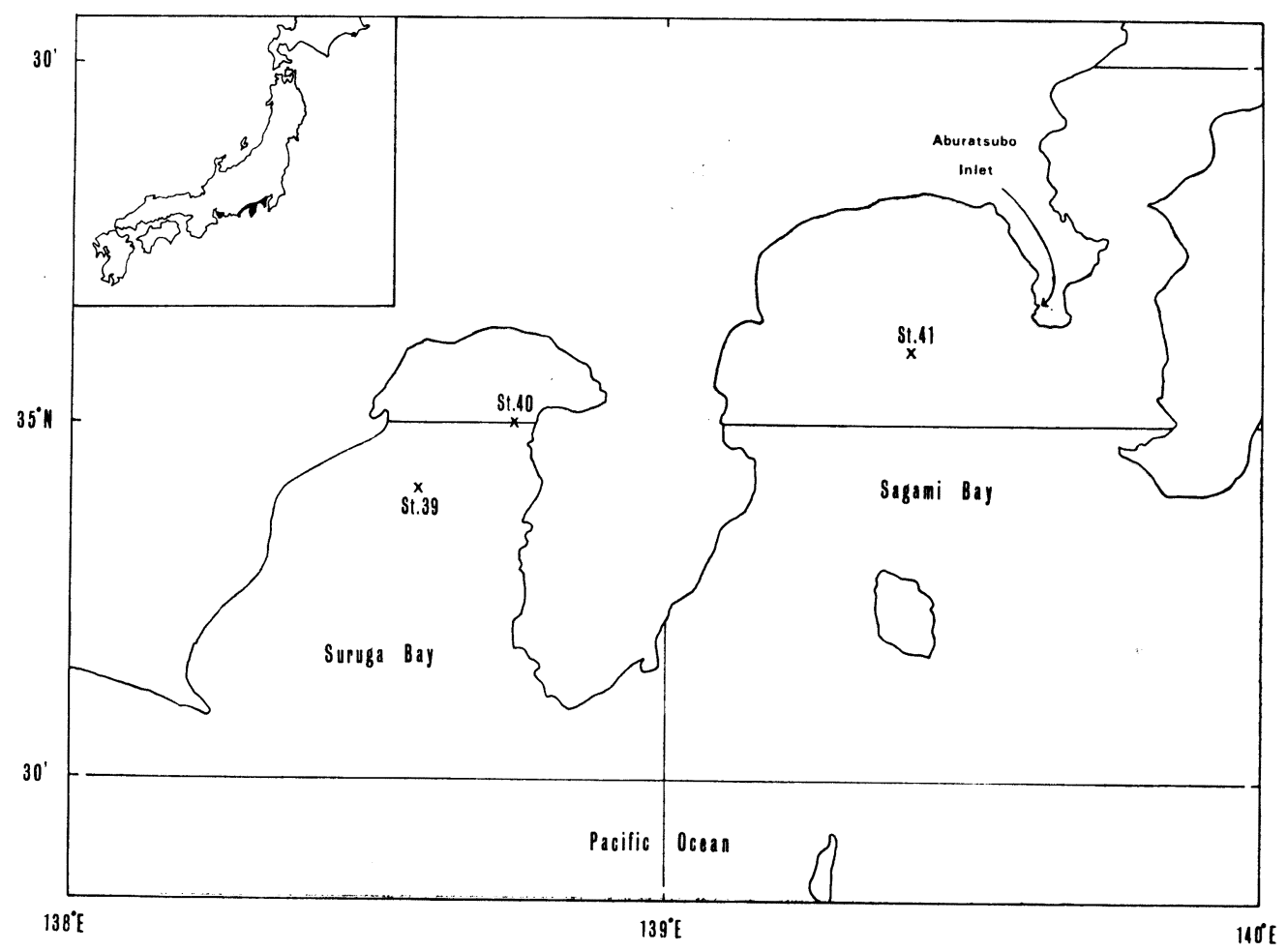

Fig. 4. Sampling stations at the Suruga Bay and the Sagami Bay. 
sity of Tokyo.

Four kinds of samplers were adopted to take the sediments; i.e., the piston corer, the Phlegertype gravity corer and the Smith-McIntyre grab were used to collect the sediments at the open sea, the Ekman-Birge sampler was particularly used at the shallow region such as the Aburatsubo Inlet.

As soon as the sediments were hauled aboard the ship, the samples were transfered aseptically to sterile Petri dishes, then a part was treated for the enumeration of heterotrophic bacteria and for the $\mathrm{pH}$ and $\mathrm{Eh}$ measurement. The rest of the samples were stored at $-20^{\circ} \mathrm{C}$ in deep freezer untill the other experiments were performed.

\section{Estimation of the bacterial number}

Three different methods were used for the enumeration of heterotropic bacteria in the sediment; i.e., surface colony counts method, membrane filter counts methods and most probable number (MPN) method.

For the method of surface colony counts, $0.1 \mathrm{ml}$ from each dilution was pipetted on to the nutrient agar plate in Petri dish and spread out evenly with a sterile spreader.

For the method of membrane filter counts, bacteria in the sediments of each dilution were collected aseptically on the sterilized Millipore ${ }^{\circledR}$ filters (Type: HA $-47 \mathrm{~mm}$ ) by filtration. The inoculated filters were placed on the nutrient agar plate in Petri dishes.

For the method of MPN counts, the standard method was used (American Public Health Association, 1965).

These inoculated plates were incubated at $20^{\circ} \mathrm{C}$ for two weeks before bacterial colonies on the plates were counted.

Following medium was used for the surface colony counts method and the membrane filter method.

PPES II Polypeptone (Daigo eiyo kagaku): 2g Proteose-peptone No. 3 (Difco): $1 \mathrm{~g}$ Bacto-soytone (Difco): $1 \mathrm{~g}$ Bacto-yeast extract (Difco): $1 \mathrm{~g}$ Ferric phosphate soluble (Merck) : 0.1g Agar (Wako):

Marine mud extract:

$15 \mathrm{~g}$

Aged sea water: $100 \mathrm{~m} l$ $\mathrm{pH}$ adjusted to 7.6 to 7.8 .
For the MPN counts method, the following medium was used;

\begin{tabular}{lr} 
Bacto-casitone (Difco): & $5 \mathrm{~g}$ \\
Beef extract: & $3 \mathrm{~g}$ \\
$\mathrm{KH}_{2} \mathrm{PO}_{4}:$ & $0.1 \mathrm{~g}$ \\
Fe-EDTA: & $6 \mathrm{mg}$ \\
$\mathrm{KNO}_{3}$ : & $0.5 \mathrm{~g}$ \\
Sea water: & $1000 \mathrm{~m} l$ \\
\multicolumn{1}{l}{ pH adjusted to 7.6 to 7.8.} &
\end{tabular}

\section{$\mathrm{PH}$ and Eh measurement}

The $\mathrm{pH}$ and redox potential of the samples were measured with $\mathrm{pH}$ meter of Model DM-1A (Toa Electronics Ltd.) and redox meter of Model RM-1 (Toa Electronics Ltd.) respectively.

\section{Estimation of loss on ignition}

In order to evaluate approximately the amount of organic matter in a sediment, loss on ignition was determined by ashing the sediment samples in a electric furnace at about $700^{\circ} \mathrm{C}$ (HANNA, 1914).

\section{Vitamin assays}

Amounts of vitamin $\mathrm{B}_{12}$, thiamine and biotin in the sediments were determined by microbiological assay method. The assay organisms and the extraction procedures used are as follows;

Vitamin $B_{12}$ Samples were extracted for 10 minutes at $120^{\circ} \mathrm{C}$ in phosphate-citrate buffer $(\mathrm{pH}$ 4.5) containing $0.01 \%$ of $\mathrm{KCN}$. Aliquots of each extract were assayed using Lactobacillus leichmannii ATCC 7830 (IFO 3376*) as an assay organism (The Association of Vitamin Chemists, 1966).

Thiamine Samples ware extracted for 30 minutes at $100^{\circ} \mathrm{C}$ in $0.2 \mathrm{~N}$ sulfuric acid solution. Assay organism used was Lactobacillus fermenti ATCC 9338 (IFO 3071) by the method of Cheldelin et al. (1946).

Biotin Samples were extracted for 30 minutes at $120^{\circ} \mathrm{C}$ in $0.2 \mathrm{~N}$ sulfuric acid solution. Saccharomyces cerevisiae ATCC 7754 (IAM 4626**) was used as an assay organism (HERTZ, 1943).

Cultures of Lact. leichmannii and Lact. fermenti were provided from the Institute for Fermentation, Osaka, and culture of Sacch. cerevisiae from the Institute of Applied Micro-

* Culture number of the Institute for Fermentation, Osaka (IFO).

** Culture number of the Institute of Applied Microbiology (IAM), University of Tokyo. 
Table 2. Vitamin contents and other characteristics of the sediments collected at the Aburatsubo Inlet (July 23, 1968).

\begin{tabular}{|c|c|c|c|c|c|c|c|c|c|}
\hline \multirow[b]{2}{*}{ Station } & \multirow{2}{*}{$\begin{array}{l}\text { Water } \\
\text { depth } \\
(\mathrm{m})\end{array}$} & \multirow{2}{*}{$\begin{array}{l}\text { Depth in } \\
\text { core } \\
(\mathrm{cm})\end{array}$} & \multirow[b]{2}{*}{$\mathrm{pH}$} & \multirow{2}{*}{$\underset{(\mathrm{mV})}{\mathrm{Eh}}$} & \multirow{2}{*}{$\begin{array}{l}\text { Loss on } \\
\text { ignition } \\
\quad(\%)\end{array}$} & \multirow{2}{*}{$\begin{array}{c}\text { Heterotrophs* } \\
\text { (cells/g } \\
\text { wet mud) }\end{array}$} & \multicolumn{3}{|c|}{ Vitamin contents** } \\
\hline & & & & & & & $\begin{array}{l}\text { Vitamin } \mathrm{B}_{12} \\
(\mathrm{~m} \mu \mathrm{g} / \mathrm{g})\end{array}$ & $\begin{array}{c}\text { thiamine } \\
(\mu \mathrm{g} / \mathrm{g})\end{array}$ & $\begin{array}{c}\text { biotin } \\
(\mathrm{m} \mu \mathrm{g} / \mathrm{g})\end{array}$ \\
\hline \multirow{6}{*}{ St. A } & \multirow[t]{6}{*}{5.8} & $0-2$ & 8.8 & 394 & 20.6 & $1.2 \times 10^{7}$ & 7.14 & 0.50 & 1.3 \\
\hline & & $2-5$ & 8.2 & 404 & 21.2 & $2.0 \times 10^{6}$ & 9.30 & 0.80 & 2.3 \\
\hline & & $5-10$ & 8.3 & 64 & 14.7 & $1.0 \times 10^{6}$ & 6.80 & 0.68 & 1.8 \\
\hline & & $10-15$ & 8.6 & 24 & 24.3 & $1.0 \times 10^{7}$ & 5.28 & 0.65 & 0.5 \\
\hline & & $15-20$ & 8.3 & -76 & 18.0 & & 2.00 & 0.52 & 1.2 \\
\hline & & $20-25$ & 9.0 & 244 & 15.8 & $4.0 \times 10^{6}$ & 1.83 & 0.45 & 0 \\
\hline St. B & 2.0 & 0 & 7.9 & 297 & 9.5 & $4.0 \times 10^{6}$ & 1.99 & 0.37 & 0.8 \\
\hline St. C & 5.4 & 0 & 7.6 & 139 & 19.0 & $4.0 \times 10^{7}$ & 2.14 & 0.53 & 0.9 \\
\hline St. D & 1.0 & 0 & 7.6 & 334 & 8.0 & $6.0 \times 10^{6}$ & 1.14 & 0.26 & 2.6 \\
\hline \multirow[t]{7}{*}{ St. E } & \multirow[t]{7}{*}{6.0} & $0-2$ & 8.9 & 324 & 18.6 & $1.0 \times 10^{7}$ & 4.94 & 0.16 & 1.4 \\
\hline & & $2-4$ & 8.8 & 314 & 17.7 & $2.0 \times 10^{7}$ & 3.06 & 0.23 & 1.3 \\
\hline & & $4-8$ & 8.8 & 244 & 13.9 & $1.0 \times 10^{7}$ & 3.58 & & 1.7 \\
\hline & & $8-15$ & 8.6 & 224 & 18.2 & $1.0 \times 10^{7}$ & 4.41 & 0.09 & 1.1 \\
\hline & & $15-20$ & 8.6 & 174 & 15.7 & & 5.83 & $\operatorname{tr} * * *$ & 1.1 \\
\hline & & $20-25$ & 9.0 & 288 & 11.0 & & 3.83 & $\operatorname{tr}$ & 0.6 \\
\hline & & $25-30$ & 9.0 & 214 & 9.7 & & 2.07 & $\operatorname{tr}$ & 0.5 \\
\hline
\end{tabular}

* These numbers were estimated by the surface colony counts method.

** Values per dry weight are represented.

*** $\operatorname{tr}$ represents undetectable amounts.

Table 3. Vitamin contents and other characteristics of the deep sediments collected at the Japan Trench and its adjacent region.

\begin{tabular}{|c|c|c|c|c|c|c|c|c|}
\hline \multirow{2}{*}{$\begin{array}{l}\text { Station } \\
\text { number }\end{array}$} & \multirow{2}{*}{$\begin{array}{l}\text { Depth in } \\
\text { core } \\
(\mathrm{cm})\end{array}$} & \multirow[b]{2}{*}{$\mathrm{pH}$} & \multirow[b]{2}{*}{$\underset{(\mathrm{mV})}{\mathrm{Eh}}$} & \multirow{2}{*}{$\begin{array}{c}\text { Loss on } \\
\text { ignition } \\
(\%)\end{array}$} & \multirow{2}{*}{$\begin{array}{l}\text { Heterotrophs* } \\
\text { (cells/g } \\
\text { wet mud) }\end{array}$} & \multicolumn{3}{|c|}{ Vitamin contents ${ }^{* *}$} \\
\hline & & & & & & $\begin{array}{l}\operatorname{vitamin} B_{12} \\
(\mathrm{~m} \mu \mathrm{g} / \mathrm{g})\end{array}$ & $\begin{array}{c}\text { thiamine } \\
(\mu \mathrm{g} / \mathrm{g})\end{array}$ & $\begin{array}{c}\text { biotin } \\
(\mathrm{m} \mu \mathrm{g} / \mathrm{g})\end{array}$ \\
\hline 1 & 0 & 7.6 & 363 & 6.0 & & 0.18 & 0.11 & 2.1 \\
\hline 2 & 0 & 7.0 & 408 & 6.3 & $1.0 \times 10^{4}$ & 0.20 & 0.12 & 1.8 \\
\hline 3 & 0 & 7.0 & 408 & 5.6 & $1.5 \times 10^{4}$ & 0.29 & 0.16 & 1.4 \\
\hline 4 & 0 & 7.8 & 338 & 7.3 & $1.0 \times 10^{5}$ & 0.14 & 0.10 & 2.4 \\
\hline \multirow[t]{2}{*}{5} & $0-5$ & 8.2 & 328 & 13.9 & $1.2 \times 10^{2}$ & 1.20 & 0.39 & 1.5 \\
\hline & $15-20$ & 8.4 & 359 & 4.5 & $3.0 \times 10^{2}$ & 0.30 & 0.11 & 0.9 \\
\hline \multirow[t]{2}{*}{6} & $0-5$ & 7.6 & 322 & 5.4 & $6.0 \times 10^{2}$ & 2.10 & 0.06 & 1.5 \\
\hline & $15-20$ & 8.6 & 375 & 4.3 & $5.0 \times 10$ & 0.46 & 0.06 & 1.3 \\
\hline 7 & 0 & 8.5 & 361 & 5.2 & $1.0 \times 10^{5}$ & 2.80 & 0.09 & 2.4 \\
\hline \multirow[t]{2}{*}{8} & $0-5$ & 8.3 & 351 & 4.9 & $1.7 \times 10^{3}$ & 0.76 & 0.15 & 1.7 \\
\hline & $15-20$ & 8.5 & 362 & 5.5 & & 0.29 & 0.05 & 1.6 \\
\hline
\end{tabular}

* These numbers were estimated by the membrane filter counts method.

** Values per dry weight are represented.

biology, University of Tokyo.

\section{Results}

Vitamin contents and other characteristics of the sediments collected at the different 41 stations are presented in Tables 2, 3, 4, 5 and 6 .

Nature of the sediment samples

The sediments from St. A, St. C and St. D of the Aburatsubo Inlet were similar in appearance, consisting of muds, having a slight odour of hydrogen sulfide. The values of loss on ignition and the population of heterotrophic bacteria in the samples were also similar levels and did not have clear trend from surface to 30 $\mathrm{cm}$ depth of core. The sediments from St. B, composed of granule, and the sample from St. 
Table 4. Vitamin contents and other characteristics of the sediments collected at the Mid-Pacific Ocean.

\begin{tabular}{|c|c|c|c|c|c|c|c|c|}
\hline \multirow{2}{*}{$\begin{array}{l}\text { Station } \\
\text { number }\end{array}$} & \multirow{2}{*}{$\begin{array}{l}\text { Depth in } \\
\text { core } \\
(\mathrm{cm})\end{array}$} & \multirow[b]{2}{*}{$\mathrm{pH}$} & \multirow[b]{2}{*}{$\underset{(\mathrm{mV})}{\mathrm{Eh}}$} & \multirow{2}{*}{$\begin{array}{l}\text { Loss on } \\
\text { ignition } \\
(\%)\end{array}$} & \multirow{2}{*}{$\begin{array}{c}\text { Heterotrophs* } \\
\text { (cells/g } \\
\text { wet mud) }\end{array}$} & \multicolumn{3}{|c|}{ Vitamin contents** } \\
\hline & & & & & & $\underset{(\mathrm{m} \mu \mathrm{g} / \mathrm{g})}{\operatorname{vitamin}} \mathrm{B}_{12}$ & $\begin{array}{l}\text { thiamine } \\
(\mu \mathrm{g} / \mathrm{g})\end{array}$ & $\begin{array}{l}\text { biotin } \\
(\mathrm{m} \mu \mathrm{g} / \mathrm{g})\end{array}$ \\
\hline \multirow[t]{4}{*}{9} & $0-5$ & 7.8 & 321 & 9.4 & $3 \times 10^{6}$ & 1.32 & 0.79 & 1.7 \\
\hline & $10-15$ & 8.0 & 332 & 9.1 & $8 \times 10^{5}$ & 1.57 & 1.07 & 1.5 \\
\hline & $30-35$ & 7.1 & 379 & 10.0 & & 0.79 & 0.79 & 0.7 \\
\hline & $45-50$ & 7.6 & 310 & 9.2 & & 2.99 & 0.27 & 0 \\
\hline 10 & 0 & 8.6 & 365 & 9.1 & below $10^{3}$ & 0.64 & 0.14 & 6.2 \\
\hline 11 & 0 & 8.6 & 366 & 26.4 & $9 \times 10^{6}$ & 1.03 & 0.13 & 4.8 \\
\hline 12 & 0 & 8.3 & 346 & 19.7 & $2 \times 10^{4}$ & 1.06 & 0.10 & 8.1 \\
\hline \multirow[t]{3}{*}{13} & $0-5$ & 8.5 & 364 & 22.5 & $7 \times 10^{3}$ & 0.93 & & 7.3 \\
\hline & $30-35$ & 8.7 & 373 & 12.1 & below $10^{3}$ & 0.63 & & 3.1 \\
\hline & $60-65$ & 8.7 & 372 & 24.7 & below $10^{3}$ & 1.01 & & $\operatorname{tr} * * *$ \\
\hline \multirow[t]{3}{*}{14} & $0-5$ & & & 26.6 & $5 \times 10^{2}$ & 1.47 & & \\
\hline & $20-25$ & & & 14.5 & $8 \times 10^{3}$ & $\operatorname{tr}$ & & \\
\hline & $75-80$ & & & 13.8 & $6 \times 10^{2}$ & $\operatorname{tr}$ & & \\
\hline \multirow[t]{3}{*}{15} & $0-5$ & & & 8.6 & $3 \times 10^{3}$ & & $\operatorname{tr}$ & 5.1 \\
\hline & $20-25$ & & & 10.0 & 5 & & 1.15 & 4.0 \\
\hline & $85-90$ & & & 16.3 & below 10 & & 0.74 & 4.2 \\
\hline 16 & 0 & & & 5.5 & below 10 & & 0.23 & 2.4 \\
\hline \multirow[t]{3}{*}{17} & $0-5$ & & & 13.4 & $2 \times 10^{4}$ & & 0.91 & 4.9 \\
\hline & $20-25$ & & & 10.2 & $3 \times 10^{2}$ & & & 3.9 \\
\hline & $45-50$ & & & 11.7 & $1 \times 10^{3}$ & & & 7.6 \\
\hline
\end{tabular}

* These numbers were estimated by the surface colony counts method.

** Values per dry weight are represented. $\quad{ }^{* * *} \operatorname{tr}$ represents undetectable amounts.

Table 5. Vitamin contents and other characteristics of the sediments collected at the Eastern China Sea.

\begin{tabular}{|c|c|c|c|c|c|c|c|}
\hline \multirow{2}{*}{$\begin{array}{l}\text { Station } \\
\text { number }\end{array}$} & \multirow[b]{2}{*}{$\mathrm{pH}$} & \multirow{2}{*}{$\underset{(\mathrm{mV})}{\mathrm{Eh}}$} & \multirow{2}{*}{$\begin{array}{c}\text { Loss on } \\
\text { ignition } \\
(\%)\end{array}$} & \multirow{2}{*}{$\begin{array}{l}\text { Heterotrophs* } \\
\text { (cells/g wet mud) }\end{array}$} & \multicolumn{3}{|c|}{ Vitamin contents** } \\
\hline & & & & & $\begin{array}{l}\text { vitamin } B_{12} \\
(\mathrm{~m} \mu / \mathrm{g})\end{array}$ & $\begin{array}{c}\text { thiamine } \\
(\mu \mathrm{g} / \mathrm{g})\end{array}$ & $\begin{array}{c}\text { biotin } \\
(\mathrm{m} \mu \mathrm{g} / \mathrm{g})\end{array}$ \\
\hline 18 & 8.2 & 347 & 3.6 & \multirow{5}{*}{$3.5 \times 10^{5}$} & 0.06 & 0.26 & 0.9 \\
\hline 19 & 8.0 & 337 & 9.5 & & 0.45 & 0.39 & 1.8 \\
\hline 20 & 8.5 & 335 & 8.2 & & 0.98 & 0.15 & 1.0 \\
\hline 21 & 8.4 & 330 & 12.0 & & 1.37 & 0.31 & 3.7 \\
\hline 22 & 7.8 & 319 & 9.9 & & 1.93 & 1.34 & 3.4 \\
\hline 23 & 8.2 & 317 & 4.2 & \multirow{4}{*}{$1.6 \times 10^{6}$} & 0.97 & 0.24 & 0.6 \\
\hline 24 & 8.5 & 337 & 2.9 & & 0.95 & 0.15 & 2.0 \\
\hline 25 & 8.1 & 325 & 4.4 & & 0.40 & & 0.4 \\
\hline 26 & 8.6 & 346 & 4.0 & & 1.18 & $\operatorname{tr}^{* * *}$ & 0.2 \\
\hline 27 & 8.3 & 325 & 5.8 & \multirow{6}{*}{$2.2 \times 10^{5}$} & 0.94 & 0.14 & 0.9 \\
\hline 28 & 8.6 & 346 & 6.4 & & 1.10 & 0.20 & 1.7 \\
\hline 29 & 8.2 & 340 & 7.2 & & 0.75 & 0.64 & 2.2 \\
\hline 30 & 7.9 & 326 & 7.3 & & 0.59 & 0.75 & 1.4 \\
\hline 31 & 8.4 & 335 & 12.8 & & 0.82 & 0.21 & 2.0 \\
\hline 32 & 8.4 & 329 & 5.9 & & 1.22 & 0.33 & 2.1 \\
\hline 33 & 8.7 & 346 & 6.0 & \multirow{3}{*}{$1.7 \times 10^{5}$} & 1.17 & $\operatorname{tr}$ & 0.4 \\
\hline 34 & 8.5 & 340 & 6.3 & & 0.50 & $\operatorname{tr}$ & 1.1 \\
\hline 35 & 7.5 & 303 & 7.0 & & 0.44 & 0.80 & 2.0 \\
\hline 36 & 8.0 & 352 & 6.4 & \multirow{3}{*}{$1.3 \times 10^{5}$} & 0.31 & 0.63 & 2.4 \\
\hline 37 & 8.4 & 332 & 4.8 & & 0.19 & 0.10 & 0.5 \\
\hline 38 & 8.3 & 326 & 1.5 & & 0.30 & $\operatorname{tr}$ & 1.0 \\
\hline
\end{tabular}

* These numbers were estimated by the most probable number method.

** Values per dry weight are represented. $\quad * * * \operatorname{tr}$ represents undetectable amounts. 
Table 6. Vitamin contents and other characteristics of the sediments collected at the Suruga Bay and the Sagami Bay.

\begin{tabular}{ccccccc}
\hline $\begin{array}{c}\text { Station } \\
\text { number }\end{array}$ & $\begin{array}{c}\text { Depth in } \\
\text { core } \\
(\mathrm{cm})\end{array}$ & $\begin{array}{c}\text { Loss on } \\
\text { ignition } \\
(\%)\end{array}$ & $\begin{array}{c}\text { Heterotrophs* } \\
(\text { cells/g wet mud) }\end{array}$ & $\begin{array}{c}\text { vitamin } \mathrm{B}_{12} \\
(\mathrm{~m} \mu \mathrm{g} /)\end{array}$ & $\begin{array}{c}\text { thiamine } \\
(\mu \mathrm{g} / \mathrm{g})\end{array}$ & $\begin{array}{c}\text { iotin } \\
(\mathrm{m} \mu \mathrm{g} / \mathrm{g})\end{array}$ \\
\hline 39 & 0 & 4.3 & $9.2 \times 10^{4}$ & 0.57 & 0.12 & 2.5 \\
40 & 0 & 5.3 & $5.4 \times 10^{5}$ & 0.40 & 0.06 & 0.6 \\
41 & $0-3$ & 15.8 & $7.9 \times 10^{4}$ & tr*** & 0.70 & 5.7 \\
& $6-9$ & 15.2 & & 1.14 & 0.44 & 4.9 \\
& $12-15$ & 10.9 & & 0.39 & 0.35 & 5.9 \\
& $21-24$ & 11.6 & $3.3 \times 10^{3}$ & 0.27 & 0.21 & 1.1 \\
& $33-36$ & 10.2 & & 0.34 & 0.14 & 4.5 \\
& 45 & 10.4 & & 0.34 & 0.15 & 2.9 \\
\hline
\end{tabular}

* These numbers were estimated by the most probable number method.

** Values per dry weight are represented.

*** $\operatorname{tr}$ represents undetectable amounts.

$\mathrm{D}$, composed of sand had lower values of loss on ignition.

The $\mathrm{pH}$ values of the deep sea sediments of the Japan Trench lay between 7.0 and 8.7, and the Eh between 322 and $408 \mathrm{mV}$. These values are close to others found for red clay and other deep sea sediments (BAAS BECKING, KAPLAN and MOORE, 1960). The population of heterotrophic bacteria in the deep sea sediments enumerated by the membrane filter counts method was range from $10^{2}$ to $10^{4}$ per gram (wet weight).

The sediment samples of the Mid-Pacific Ocean were composed of red clay in the area deeper than about 4,500 meters, on the other hand, the shallower sediments were consisted of foraminifera ooze. All the samples showed quite oxidizing conditions.

The surface sediments collected at the Eastern China Sea, consisting of fine sand or silt, showed lower values of loss on ignition than the sediments at the other parts used in this study. Population of heterotrophic bacteria estimated with MPN counts method was range from $10^{5}$ to $10^{6}$ per gram (wet weight).

Distribution of vitamins in the surface sediments

Surface samples from the Aburatsubo Inlet have been found to range from 1.14 to $7.14 \mathrm{~m} \mu \mathrm{g}$ of vitamin $B_{12}$ per gram of dry weight, 0.16$0.53 \mu \mathrm{g}$ of thiamine and $0.8-2.6 \mathrm{~m} \mu \mathrm{g}$ of biotin. Except for the biotin content of St. D, vitamins were found more abundantly in the muddy sediments (St. A, St. C and St. E) than in the sandy or granular sediments. This result agrees
Table 17. Analysis of variance of logarismic transformed values of three vitamin contents in the sediments from five different areas.

Vitamin $\mathrm{B}_{12}$

\begin{tabular}{lrrrr}
\hline Factor & s.s. & d.f. & m.s. & \multicolumn{1}{c}{$\mathrm{F}_{0}$} \\
\hline Area & 4193.2 & 4 & 1048.3 & $4.40^{* *}$ \\
Residual & 8569.3 & 36 & 238.0 & \\
\hline Total & 12762.5 & 40 & & \\
\hline
\end{tabular}

** Significant at $1 \%$ level.

Thiamine

\begin{tabular}{lrccc}
\hline Factor & s.s. & d.f. & m.s. & Fo $_{0}$ \\
\hline Area & 148.6 & 4 & 37.2 & 0.44 \\
Residual & 3059.4 & 36 & 85.0 & \\
\hline Total & 3208.0 & 40 & & \\
\hline \multicolumn{5}{c}{ Not significant at $5 \%$ level. }
\end{tabular}

Biotin

\begin{tabular}{lrrrc} 
Factor & s.s. & d.f. & m.s. & \multicolumn{1}{c}{ F $_{0}$} \\
\hline Area & 20402 & 4 & 5101 & $5.88^{* *}$ \\
Residual & 32977 & 38 & 868 & \\
\hline Total & 53379 & 42 & & \\
\hline
\end{tabular}

** Significant at $1 \%$ level.

well with the observation by STARR (1956).

Both vitamin $B_{12}$, thiamine and biotin were found in significant amounts in the deep sea sediments from the Japan Trench. In average concentrations were observed $0.80 \mathrm{~m} \mu \mathrm{g}$ of vitamin $\mathrm{B}_{12}$ per gram, $0.17 \mu \mathrm{g}$ of thiamine and $1.7 \mathrm{~m} \mu \mathrm{g}$ of biotin in the sediments at this rigion. These values were not so lower than the values found in the samples from the other shallower areas. 


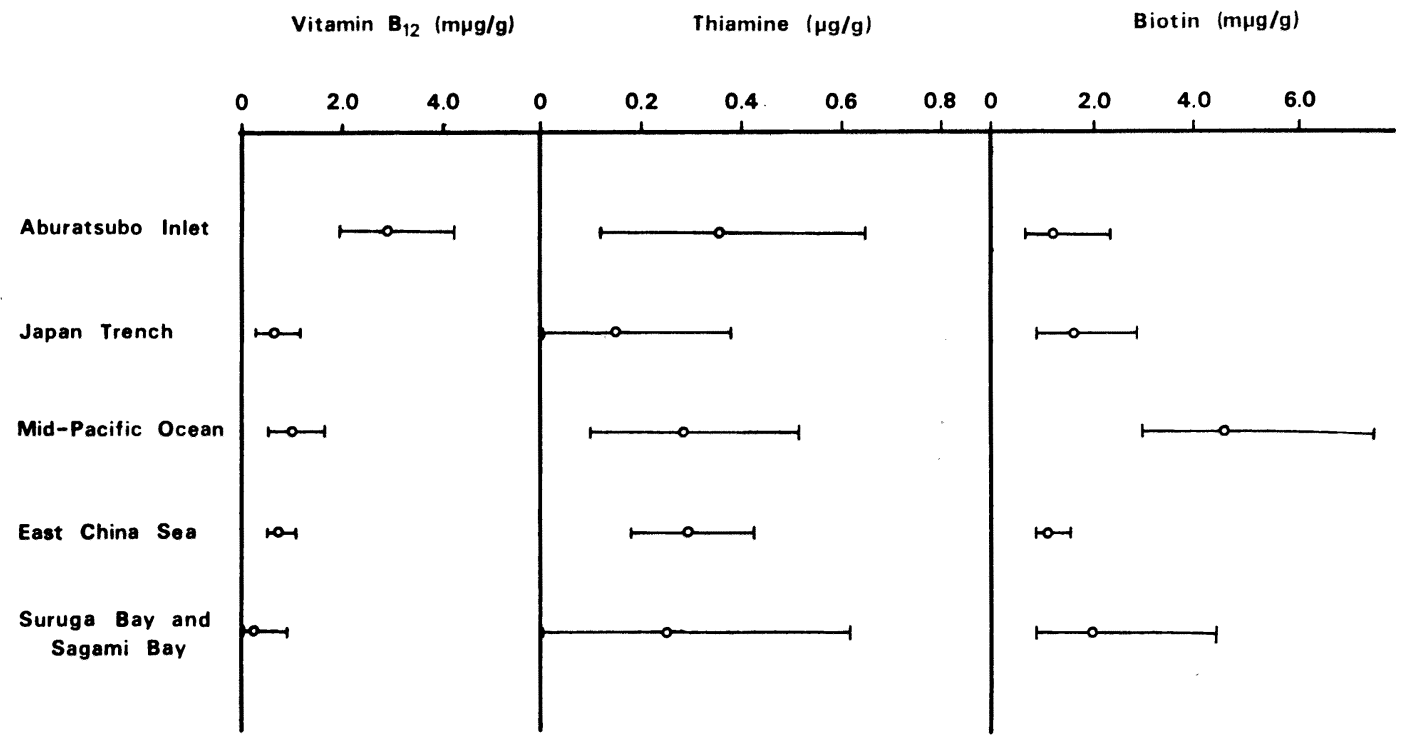

Fig. 5. The mean with the $95 \%$ confidence interval of the estimated values of three vitamins from five different areas.
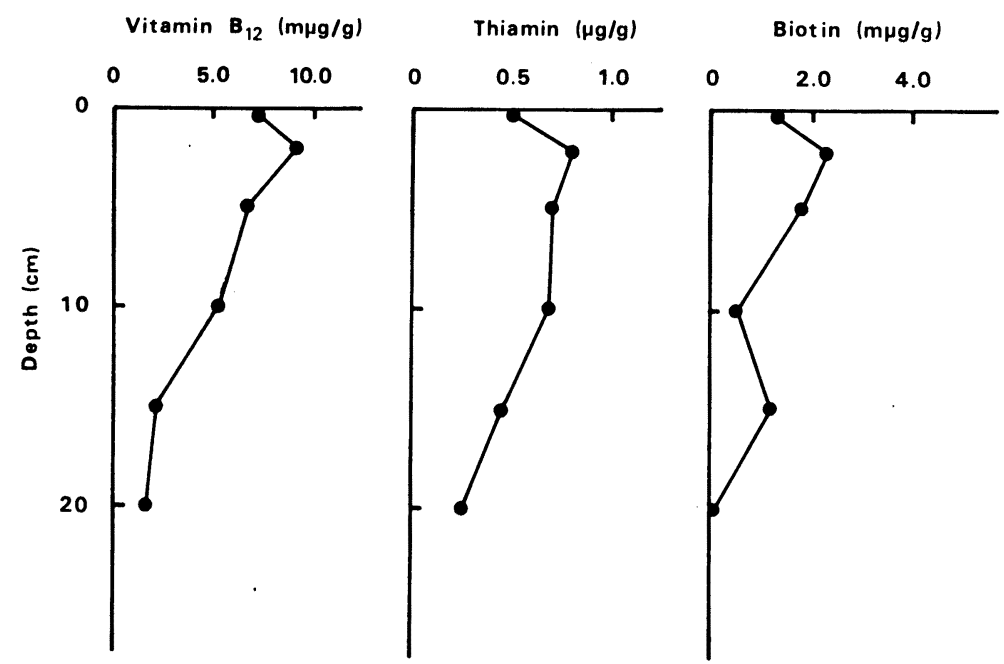

Fig. 6. Profile of distribution of vitamins and some environmental factors in the core collected at St. A in the Aburatsubo Inlet (July 23, 1968).

In order to confirm if there exist significant differences in the concentrations of each vitamin in the surface sediments among the five different areas, the data were examined statistically by the analysis of variance. The results obtained are given in Table 7. According to the result, the significant differences were defined in the vitamin $B_{12}$ contents and biotin contents among the five

different areas at $1 \%$ level, on the other hand, thiamine contents were found not to be significant at $5 \%$ level.

The estimated mean values of vitamin contents with the $95 \%$ confidence intervals in the sediments at the five areas are shown in Fig. 5. It could be considered from this figure that the concentrations of vitamin $B_{12}$ in the sediments 

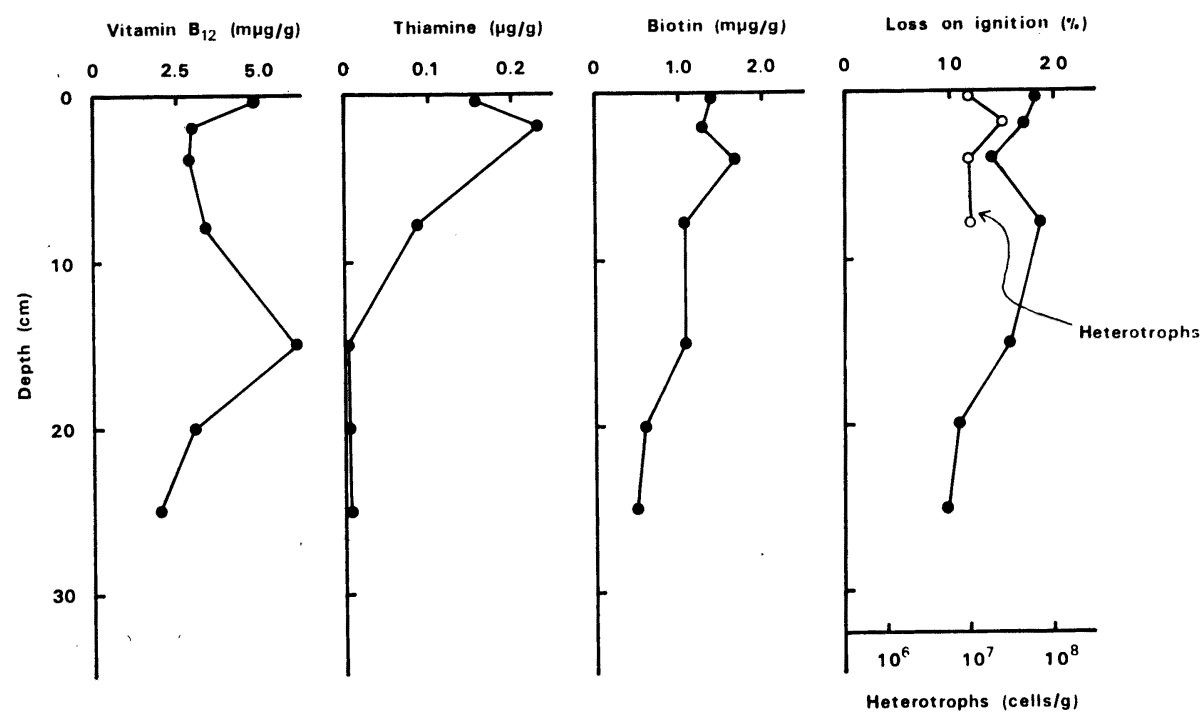

Fig. 7. Profile of distribution of vitamins, population of heterotrophic bacteria and value of loss on ignition in the core collected at St. E. in the Aburatsubo Inlet (July 23, 1968).
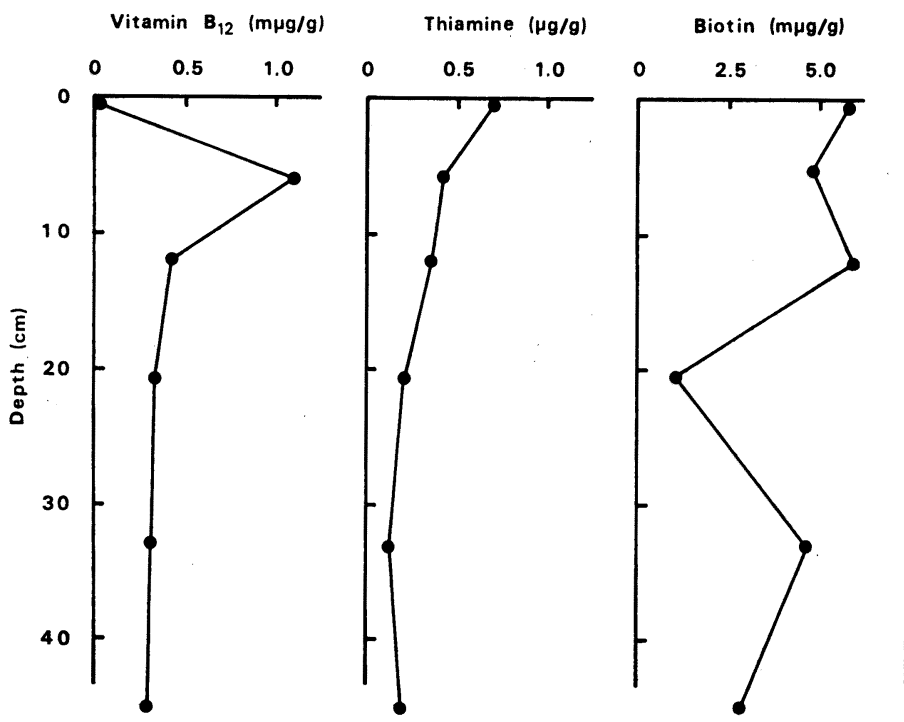

Loss on ignition $(\%)$

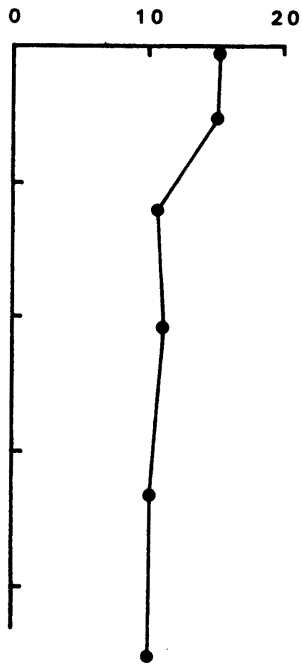

Fig. 8. Profile of distribution of vitamins and value of loss on ignition in the core collected at St. 41 in the Sagami Bay.

at the Aburatsubo Inlet were relatively higher than the concentrations at the other areas, whereas, there were not so much differences in the thiamine contents among the five areas. The sediments at the Mid-Pacific Ocean seemed to be richer in biotin than the sediments at the other areas.
Vertical distribution of the vitamins in the sediments

Vertical distribution of each vitamin in the sediments seems to have the general tendency that there exists the general decreasing slope even if it sometimes increases along the core depths. The examples of profile of distribution 


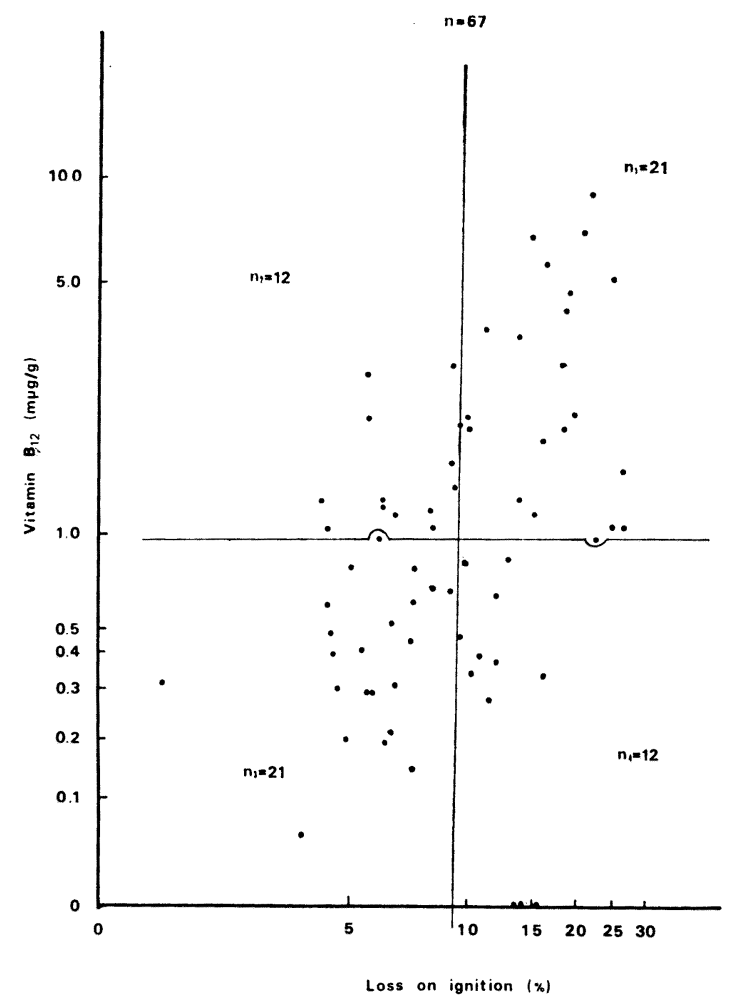

Fig. 9. Relation between vitamin $B_{12}$ contents and value of loss on ignition in the sediments examined by the Sign Test.

of vitamins and some environmental factors in the cores are given in Fig. 6, Fig. 7 and Fig. 8. Relation between the vitamin contents and the environmental factors

Relation between the contents of each vitamin and each environmental factor was examined statistically by the Sign Test. It will be obvious from Fig. 9 that there exists significant correlation between vitamin $\mathrm{B}_{12}$ contents and values of loss on ignition in the sediments at $5 \%$ level.

A significant correlation was found also between thiamine contents and values of loss on ignition at $1 \%$ level, as shown in Fig. 10, but no clear relationship between biotion contents and values of loss on ignition was found. There could not be found any correlation between the contents of each vitamin and population of heterotrophic bacteria, $\mathrm{pH}$ values or $\mathrm{Eh}$ values.

\section{Discussion}

The assay organism, Lactobacillus leichmannii, responds to several of the vitamin $B_{12}$-factors

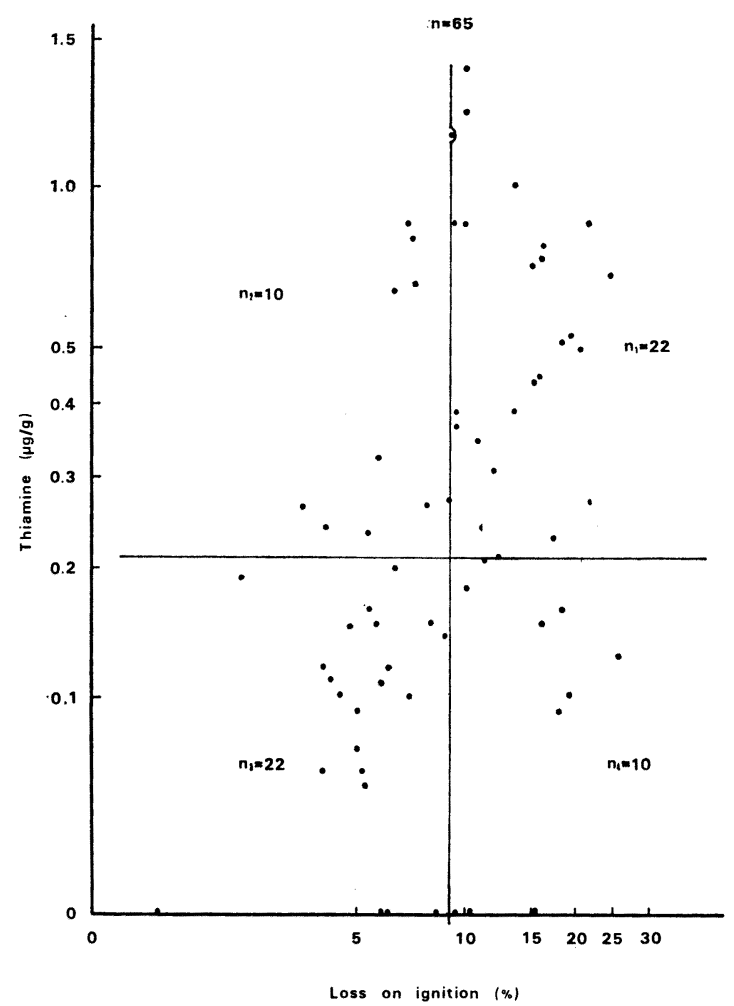

Fig. 10. Relation between thiamine contents and value of loss on ignition in the sediments examined by the Sign Test.

and deoxiribosides except for factor $\mathrm{B}$, factor $\mathrm{D}$ and factor E (COATES and FORD, 1955). BURKHOLDER and BURKHOLDER (1956) assayed marsh muds collected along the coast of Georgia for vitamin $\mathrm{B}_{12}$ by Escherichia coli mutant 313, and reported $0.670-0.757 \mu \mathrm{g}$ of vitamin $\mathrm{B}_{12}$ per gram of mud (dry weight). By the same assay organism, STARR (1956) found average of $0.13 \mu \mathrm{g}$ of vitamin $\mathrm{B}_{12}$ per gram in the marsh muds and average of $0.07 \mu \mathrm{g}$ per gram in the sandy sediments. E. coli is known to be able to make use of most of the known natually occurring forms of vitamin $B_{12}$. Although the vitamin $B_{12}$ concentrations of shallow muds in the Aburatsubo Inlet assayed by the present authors were remarkably different from those of the marsh muds which were obtained by the former authors, these discrepancies may be somewhat attributable to the difference of the assay organisms used in each case. HASHIMOTO (1954) observed 8-38 $\mathrm{m} \mu \mathrm{g}$ of vitamin $\mathrm{B}_{12}$ per gram in bottom muds 
of the fresh water ponds by using Euglena gracilis as an assay organism. Euglena gracilis responds to several of the vitamin $B_{12}$-factors, in much the same fashion as Lact. leichmannii (COATES and FORD, . 1955). These values were similar levels to the values found in the sediments from the Aburatsubo Inlet.

Incubation time of thiamine assay by Lact. fermenti was adopted 24 hours in the present study. Higher values of thiamine were obtained by the assay organism, Lact. fermenti, than those assayed by Lact. viridescens, which is known to respond only to intact molecules of thiamine, in the analysis of the same samples. This difference may be taken to indicate that Lact. fermenti responds also to pyrimidine and thiazole moieties in addition to thiamine at the assay condition adopted. HUTCHINSON (1943) measured $2.2-3.1 \mu \mathrm{g}$ of thiamine per gram of mud (dry weight) collected at Linsley Pond, by using Phycomyces blackesleeanus, which responds to both thiazole and pyrimidine moieties. On the other hand, ROULET (1948) found $19.3 \mathrm{~m} \mu \mathrm{g}$ per gram of thiamine in the soil by the same assay organism.

Besides biotin, Saccharomyces cerevisiae makes use of desthiobiotin, biocytin and other spectrum of biotin-vitamers (RoBINSON, 1966). Values of biotin contents of the sediments, therefore, is considered to represent the values of total biotin. ROULET (1948) found $0.62 \mathrm{~m} \mu \mathrm{g}$ of biotin per gram of soil at depth of $10 \mathrm{~cm}$, decreasing to $0.23 \mathrm{~m} \mu \mathrm{g}$ per gram at $50 \mathrm{~cm}$. He also observed seasonal variation of the biotin contents in the surface soil.

Almost all the core samples used in the present study for assay of vitamins showed oxidizing condition. Although the concentrations of vita$\min \mathrm{B}_{12}$, thiamine and biotin fluctuated irregularly, there seemed to be a gentle decreasing tendency with depth in the core. According to DEGENS (1965), the concentrations of amino acids in the reducing sediments of Santa Barbara Basin, California, do not systematically decrease or increase with depth, and the values fluctuate around the $500 \mathrm{~m} \mu \mathrm{g}$ level per gram of sediment. While, amino acids in oxidizing sediments show a trend to diminish with depth, probably approaching "steady state" conditions at a depth of 2.5 meters. If the sediment cores having reducing condition were examined, the different patterns of the vertical distributions of vitamin $B_{12}$, thiamine or biotin might be observed similarly as those of amino acids.

Vitamins found in sediments are considered to be mainly originated with the activities of microbes. LOCHHEAD (1957), in his study on the synthesis of B-vitamins by the predominant bacerial flora, found that out of 107 isolates from the soil, $35.5 \%$ of them were thiamine producers, $19.6 \%$ biotin producers, $39.2 \%$ riboflavin producers, $29.9 \%$ vitamin $\mathrm{B}_{12}$ producers and $50.5 \%$ producers of one or more factors. As for marine bacteria, it has been reported that physiologically significant amounts of biotin and thiamine were produced by about half of the 1,054 isolates, while nicotinic acid and vitamin $B_{12}$ were synthesized by somewhat fewer isolates (BURKHOLDER, 1963). Preliminary result of the present authors has also shown that out of 68 strains isolated from the sediments at the Mid-Pacific Ocean, 20 cultures synthesized significant amounts of biotin, 18 isolates of vitamin $B_{12}$ and 12 isolates of thiamine. Accordingly, it might be assumed from the above-mentioned results that the bacterial population and their activity producing vitamins would influence on the vitamin content of a sediment in situ as one of the environmental factors.

The activities of bacteria are influenced by many environmental factors, such as temperature, $\mathrm{pH}$ value, Eh value, organic matter etc. (ZOBELL, 1946). In the present study, $\mathrm{pH}$ value, Eh value, organic matter approximated by value of loss on ignition and population of heterotrophic bacteria in the sediments were examined as to the relations with vitamin contents. Positive correlations between values of loss on ignition and vitamin $\mathrm{B}_{12}$ or thiamine contents were found statistically. On the other hand, no clear relationship was found between values of loss on ignition of sediments and their biotin contents. Relations between vitamin contents and population of heterotrophic bacteria, $\mathrm{pH}$ values or Eh values did not show any correlations in the present study. It would be possible, however, from the previously mentioned findings (LOCHHEAD, 1957; BURKHOLDER, 1963) that the content of each 
vitamin was related to the bacterial population producing each vitamin.

As to the concentrations of vitamins dissolved in sea water, it has been reported that vitamin $\mathrm{B}_{12}$ in the North Pacific Ocean was from undetectable amounts to $3.7 \mathrm{~m} \mu \mathrm{g} / l$ (CARLUCCI and Silbernagel, 1966), thiamine in the Pacific Ocean 0 to $147 \mathrm{~m} \mu \mathrm{g} / l$ (NATARAJAN and DUGDALE, 1966) and biotin in the Gulf of Mexico 0 to $4.6 \mathrm{~m} \mu \mathrm{g} / l$ (LiTCHFIELD and HoOD, 1965). It has been also reported that inland and coastal waters contain higher levels of vitamins. VISHNIAC and RILEY (1961) observed 3.9-16 $\mathrm{m} \mu \mathrm{g} / \mathrm{l}$ of vitamin $B_{12}$ in Long Island Sound, NATARAJAN and DUGDALE (1966) found an average of 184 $\mathrm{m} \mu \mathrm{g} / l$ of thiamine and CARLUCCI and BELSER (1963) observed $10 \mathrm{~m} \mu \mathrm{g} / l$ of biotin in sea water off the pier at the Scripps Institution of Oceanography. Each vitamin content in the sediments, according to the present study, were about 1,000 times higher than that in sea water, which was reported by other authors. This finding seems to be very significant in view of the vitamin cycles in the sea, as it was suggested previously by PROVASOLI (1960) that the origin of vitamin $B_{12}$ could be located in the muds.

\section{Acknowledgements}

The authors wish to express sincere gratitude to Prof. Dr. Claude E. ZoBElL, Scripps Institution of Oceanography, University of California, for providing them the opportunity to collect the sediments at the Japan Trench, and to Captain Alan PHINNEY, the other officers and crew of $\mathrm{R} / \mathrm{V}$ Argo of the Scripps Institution of Oceanography for their help during the cruise. Appreciation is also extended to Prof. Dr. N. NASU and Dr. M. HORIKOSHI, Ocean Research Institute, University of Tokyo, for their encouragements and for making opportunities for collecting the sediments, and to Dr. T. IsHII, the same Institute, for his valuable advices on the statistical treatment of the data. We are grateful to Ex-Captain G. TANAKA, Captain T. ShIRAsawa, the other officers and crew of R/V Hakuho-maru, Ocean Research Institute, University of Tokyo, and to Captain H. SHIMAMUNE, the other officers and crew of $\mathrm{R} / \mathrm{V}$ Tansei-maru, the same Institute, for their cooperation in the cruise. Thanks are due to Dr. K. Yamasato, Institute of Applied Microbiology, University of Tokyo, and Mr. I. Sugahara, Research Institute for Food Science, University of Kyoto, for having kindly supplied some of the data of microbiological observations.

\section{References}

American Public Health Association, Inc. (1965): Standard Method for the Examination of Water and Wastewater. 12 edition.

BAAS BECKING, L. G. M., I. R. KAPLAN and D. MOORE (1960): Limits of the natural environment in terms of $\mathrm{pH}$ and oxidation-reduction potentials. Jourr. Geol., 68, 243-284.

BURKHOLDER, P. R. (1963): Some nutritional relationships among microbes of sea sediments and waters. In Symposium on marine microbiology. Edited by C. H. OPPENHEIMER. C. C. Thomas, Springfield, Ill. pp. 133-150.

BURKHOLDER, P. R. and L. M. BURKHOLDER (1956): Vitamin $B_{12}$ in suspended solids and marsh muds collected along the coast of Georgia. Limnol. Oceanogr., 1, 202-208.

CARlucci, A. F. and W. L. Belser (1963): A method for the bioassay of metabolites in sea water with Serratia marinorubra. Bacteriol. Proc., p. 3.

Carlucci, A. F. and S. B. Silbernagel (1966): Bioassay of seawater. III. Distribution of vitamin $\mathrm{B}_{12}$ in the Northeast Pacific Ocean. Limnol. Oceanogr., 11, 642-646.

Cheldelin, V. H. et al (1946): Modifications in the Lactobacillus fermenti 36 assay for thiamine. Jour. Biol. Chem., 166, 779-780.

CoAtes, M. E. and J. E. Ford (1955): Methods of measurement of vitamin $\mathrm{B}_{12}$. In The biochemistry of vitamin $\mathrm{B}_{12}$. Biochemical society symposia No. 13., Cambridge University Press. pp. $36-51$.

Degens, E. T. (1965): Geochemistry of sediments a brief survey. Prentice-Hall, Englewood Cliffs, N. Y.

DROOP, M. R. (1962): Organic micronutrients. In Biochemistry and physiology of algae. Edited by R. A. LEWIN. Academic Press, N. Y. pp. 141159.

HANNA, W. J. (1964): Methods for chemical analysis of soils. In Chemistry of the soil. Edited by F. E. BEAR. Reinhold Publlishing Corporation. N. Y. pp. 474-502.

HASHIMOTO, Y. (1954): Vitamin $B_{12}$ in marine and freshwater algae. Vitamins, 1, 49-54.

HERTZ, R. (1943): Modification of the yeast-growth 
assay method for biotin. Proc. Soc. Exptl. Biol. Med., 52, 15-17.

Hutchinson, G. E. (1943): Thiamin in lake waters and aquatic organisms. Archiv. Biochem., 2, 143150.

LitCHFIELD, C. D. and D. W. Hoop (1965): Microbiological assay for organic compounds in seawater I. Quantitative assay procedures and biotin distribution. Appl. Microbiol., 13, 886-894.

LOCHHEAD, A. G. (1957): Qualitative studies of soil microorganisms: XV. Capability of the predominant bacterial flora for synthesis of various growth factors. Soil. Sci., 84, 395-403.

Natarajan, K. V. and R. O. Dugdale (1966): Bioassay and distribution of thiamine in the sea. Limnol. Oceanogr., 11, 621-629.

Provasoli, L. (1960): Growth factors in unicellular marine algae. In Perspectives in marine biology. Edited by A. A. Buzzati-Traverso, University of California Press. pp. 385-403.

Provasoli, L. (1963): Organic regulation of phytoplankton fertility. In The sea, vol. 2. Edited by M. N. HILl, Interscience Publisher Inc., N. Y. pp. 165-219.

ReID, J. L. (1966): Zetes expedition. Trans Amer. Geophy. Union, 47, 555-561.

RoBINson, F. A. (1966): The vitamin co-factors of enzyme systems. Pergamon Press.

Roulet, M. A. (1948): Recherches sur les vitamines du sol. Experientia, 4, 149-150.

SEKI, H. and C. E. Zobell (1967): Microbial assimilation of carbon dioxide in the Japan Trench. Jour. Oceanogr. Soc. Japan, 23, 182-188.

STARR, T. J. (1956): Relative amounts of vitamin $\mathrm{B}_{12}$ in detritus from oceanic and estuarine environments near Sapelo Island, Georgia. Ecology, 37, 658-664.

The Association of Vitamin Chemists, Inc. (1966): Methods of vitamin assay. 3rd edition. Interscience Publishers, N. Y.

Vishniac, H. S. and G. A. RILEY (1961): Cobalamin and thiamine in Long Island Sound: Patterns of distribution and ecological significance. Limnol. Oceanogr., 6, 36-41.

ZoBell, C. E. (1946): Marine microbiology. Chronica Botanica Company.

\section{海底土におけるビタミン $\mathrm{B}_{12}$, チアミン, ビオチンの分布 \\ 大和田 紘一 多 賀 信 夫}

要旨 東支那海大陸棚水域, 北西および中部太平洋水 域, 駿河湾, 相模湾, 油营湾などの観測点から41個の異 なった海底土試料を採取し，それら試料中のビタミン $\mathrm{B}_{12}$, チアミンおよびビオチン含量を測定した.これらビ タミンの測定は微生物定量法によって行ない, 定量菌株 としては, Lactobacillus leichmannii (ビタミン $\mathrm{B}_{12}$ ), Lactobacillus fermenti (チアミン), Saccharomyces cerevisiae (ビオチン) が用いられた. 表層底土のビタミ ン $\mathrm{B}_{12}$ の含量は, 内湾的な油壼湾に多くみられ（1.14 $7.14 \mathrm{~m} \mu \mathrm{g} / \mathrm{g})$, 日本海溝, 中部太平洋水域, 東支那海水 域および駿河湾・相模湾水域などの海底上には少なかっ
た $(0 \sim 2.10 \mathrm{~m} \mu \mathrm{g} / \mathrm{g})$. チアミン含量は, これらの水城の 間には顕著な差がみられなかった（平均 $0.31 \mu \mathrm{g} / \mathrm{g}$ ). ビオチン含量は, 中部太平洋水域の底土に多く（平均 $5.0 \mathrm{~m} \mu \mathrm{g} / \mathrm{g}$ ), 他の 4 水域では, 顕著な差が認められなか った (平均 $2.0 \mathrm{~m} \mu \mathrm{g} / \mathrm{g}$ ). 柱状試料における鉛直的変化 をみると, ビタミン含量は一般的な傾向として上層から 下層に減少することが認められた．底土中のビタミン含 量と環境要因との関係を調べた結果, ビタミン $\mathrm{B}_{12}$ およ びチアミン含量と底土の灼熱減量との間には, 正の相関 関係が認められたが，ビオチンについては，この関係が 認められなかった。 